\title{
Carbon sequestration and biodiversity following 18 years of active tropical forest restoration
}

\author{
Charlotte E. Wheeler ${ }^{\mathrm{a}, *}$, Patrick A. Omeja ${ }^{\mathrm{b}}$, Colin A. Chapman ${ }^{\mathrm{c}, \mathrm{d}}$, Martin Glipin ${ }^{\mathrm{e}}$, Charles Tumwesigye ${ }^{\mathrm{f}}$, \\ Simon L. Lewis ${ }^{\text {a,e }}$
}

${ }^{a}$ Department of Geography, University College London, London WC1E 6BT, UK

${ }^{\mathrm{b}}$ Makerere University Biological Field Station, P.O. Box 967, Fort Portal, Uganda

${ }^{\mathrm{c}}$ McGill School of Environment and Department of Anthropology, 855 Sherbrooke St. West, McGill University, Montreal H3A 2T7, Canada

${ }^{\mathrm{d}}$ Wildlife Conservation Society, Bronx, New York, United States

e School of Geography, University of Leeds, Leeds LS2 9JT, UK

${ }^{\mathrm{f}}$ Uganda Wildlife Authority, P.O. Box 3530, Kampala, Uganda

\section{A R T I C L E I N F O}

\section{Article history:}

Received 23 December 2015

Received in revised form 11 April 2016

Accepted 12 April 2016

Available online 22 April 2016

\section{Keywords:}

Forest degradation

Natural regeneration

Arrested succession

Biodiversity co-benefits

Replanting

Biomass accumulation

\begin{abstract}
A B S T R A C T
Vast areas of degraded tropical forest, combined with increasing interest in mitigating climate change and conserving biodiversity, demonstrate the potential value of restoring tropical forest. However, there is a lack of long-term studies assessing active management for restoration. Here we investigate AboveGround Biomass (AGB), forest structure, and biodiversity, before degradation (in old-growth forest), after degradation (in abandoned agricultural savanna grassland), and within a forest that is actively being restored in Kibale National Park, Uganda. In 1995 degraded land in Kibale was protected from fire and replanted with native seedlings (39 species) at a density of 400 seedlings ha ${ }^{-1}$. Sixty-five plots $(50 \mathrm{~m} \times 10 \mathrm{~m})$ were established in restoration areas in 2005 and 50 of these were re-measured in 2013, allowing changes to be assessed over 18 years. Degraded plots have an Above Ground Biomass (AGB) of $5.1 \mathrm{Mg}$ dry mass ha ${ }^{-1}$, of which $80 \%$ is grass. By 2005 AGB of trees $\geqslant 10 \mathrm{~cm} \mathrm{DBH}$ was $9.5 \mathrm{Mg} \mathrm{ha}^{-1}$, increasing to $40.6 \mathrm{Mg} \mathrm{ha}^{-1}$ by 2013 , accumulating at a rate of $3.9 \mathrm{Mg} \mathrm{ha}^{-1}$ year $^{-1}$. A total of 153 planted individuals ha ${ }^{-1}(38 \%)$ remained by 2013 , contributing $28.9 \mathrm{Mg} \mathrm{ha}^{-1}$ (70\%) of total AGB. Eighteen years after restoration, AGB in the plots was $12 \%$ of old-growth $\left(419 \mathrm{Mg} \mathrm{ha}^{-1}\right)$. If current accumulation rates continue restoration forest would reach old-growth AGB in a further 96 years. Biodiversity of degraded plots prior to restoration was low with no tree species and 2 seedling species per sample plot (0.05 ha). By 2005 restoration areas had an average of 3 tree and 3 seedling species per sample plot, increasing to 5 tree and 9 seedling species per plot in 2013. However, biodiversity was still significantly lower than old-growth forest, at 8 tree and 16 seedling species in an equivalent area. The results suggest that forest restoration is beneficial for AGB accumulation with planted stems storing the majority of AGB. Changes in biodiversity appear slower; possibly due to low stem turnover. Overall this restoration treatment is an effective means of restoring degraded land in the area, as can be seen from the lack of regeneration in degraded plots, which remain low-AGB and diversity, largely due to the impacts of fire and competition with grasses.
\end{abstract}

(c) 2016 The Authors. Published by Elsevier B.V. This is an open access article under the CC BY license (http:// creativecommons.org/licenses/by/4.0/).
Abbreviations: UWA-FACE, Uganda Wildlife Authority and FACE (Forest absorbing carbon emissions) the future foundation forest rehabilitation project; KNP, Kibale National Park; AGB, Above Ground Biomass; DBH, diameter at breast height; NMDS, non-metric multi-dimensional scaling; AGWP, above-ground wood production.

* Corresponding author.

E-mail addresses: c.wheeler.12@ucl.ac.uk (C.E. Wheeler), omejap@caes.mak.ac. ug (P.A. Omeja), colin.chapman@magill.ca (C.A. Chapman), M.B.Glipin@leeds.ac.uk (M. Glipin), charlestumwesigye@yahoo.co.uk (C. Tumwesigye), s.l.lewis@ucl.ac.uk (S.L. Lewis).

\section{Introduction}

Large areas of forest lands have been converted to other land uses, and large areas of degraded tropical forest exists, covering some 550 million ha by some estimates (Pan et al., 2011). Degraded forests and abandoned agricultural lands have the potential to recover back to higher carbon and biodiversity value forest if left to regenerate naturally. However, natural regeneration is often arrested in very heavily degraded lands (Lawes and Chapman, 
2006; Paul et al., 2004). One of the major factors leading to arrested succession is the increased susceptibility of degraded forest to wildfires (Cochrane, 2003). In addition, other factors can exacerbate arrested succession in degraded areas. Seed banks are often poor following logging or agricultural cultivation, due to topsoil removal (Dupuy and Chazdon, 1998). Seed rain from surrounding forest into degraded land can also be limited, with wind dispersed seeds often not travelling large distances (Cubiña and Aide, 2001) and animal dispersed seeds rarely found, as few forest animals pass through such areas (Holl, 1999). Thus, the distance to the nearest primary forest can determine the success of regeneration (Cubiña and Aide, 2001). This is problematic in highly fragmented habitats where only small patches of forest remain, particularly if the species composition of such fragments is not representative of oldgrowth forest.

Thus, large areas of abandoned degraded land, and their propensity for arrested succession, mean that forest restoration could play a vital role in mitigating climate change. Not only could restored forest sequester carbon, they also have the potential to aid the recovery of biodiversity and ecosystem function. Collectively these factors have increased the desirability of forest restoration, often termed Forest Landscape Restoration (Chazdon et al., 2016).

Despite active management to restore forests being suggested as a potentially important method to increase terrestrial carbon storage and improve ecosystem function of tropical forests, research is sparse. In particular, very little is known about the long-term effects of forest restoration in terms of forest structure, carbon sequestration, and changes in biodiversity. This evidence is necessary as, the costs associated with forest restoration can be considerable (Lamb et al., 2005). For example, a study by Parrotta and Knowles (1999) estimated that restoration of a bauxite mine in the Amazon cost is $\$ 2500$ per ha. Thus, it is important to quantify the benefits of active forest restoration to ensure restoration projects are successful enough in terms of the long-term recovery of ecosystem services to warrant the costs.

To begin to address this gap in current knowledge, we undertook research in the UWA-FACE (Uganda Wildlife Authority and FACE the future foundation) rehabilitation project, in Kibale National Park, Uganda (hereafter Kibale). Since 1995 this project has been restoring abandoned agricultural land that had become dominated by invasive elephant grass (Pennisetum purpureum), due to repeated wildfires (UWA-FACE, 2011). Restoration activities involved protection from fire and replanting with native tree species to restore forest ecosystem functions, and enhancing biodiversity conservation (UWA-FACE, 2007, 2011). In 2005 a study was conducted by Omeja et al. (2011a) to assess AGB and biodiversity of the project 10 years after planting.

Our aims in this study are twofold. Firstly, to quantify the effect of tree planting and fire management on AGB accumulation and plant species diversity over 18 years by remeasuring the study plots established in 2005. It is likely that the rate of AGB accumulation will change with increasing time after planting, as has been demonstrated in an Australian tropical forest restoration project (Paul et al., 2015). Specifically, we predict that initial AGB accumulation will be slow as planted seedlings have few photosynthesizing leaves, limiting growth, which will increase as the size of trees in the stand increases. Thus, we expect more recent AGB accumulation rates to be greater, and be more representative of rates over the coming decades.

Secondly, we estimate woody plant species diversity after 18 years of restoration. We expect that restoration activities will result in an increase in tree species diversity. Initially tree diversity will be dominated by planted tree species. However, the presence of planted trees is expected to assist natural regeneration and the shade created once a canopy develops will create more favourable conditions for seedlings of old-growth forest species to become established. Furthermore, the presence of planted trees will also encourage the movement of animals through the area and they will bring with them seeds of animal-dispersed species. Therefore, restoration will help increase tree diversity from pre-restoration levels, yet, it is likely to take longer for species composition to become similar to old-growth forest that forest structure of AGB due to the time delay in pioneer planted tree species being superseded by old-growth forest species.

Here, we calculate changes in forest structure, AGB and biodiversity at two periods following forest restoration, 10 years post planting in 2005 and 18 years post planting in 2013, in Kibale National Park and compare these to nearby grassland areas that have not been restored and old-growth forest that has not been degraded.

\section{Methods}

\subsection{Study site}

This study was conducted in the southern part of Kibale National Park, Uganda (E 30.31-30.36, N 0.31-0.56, Fig. 1). Kibale is a moist evergreen forest covering $795 \mathrm{~km}^{2}$. It received on average $1672 \mathrm{~mm} \mathrm{y}^{-1}$ of rainfall between 1992 and 2013 (the project duration). Rainfall distribution is bi-modal with two pronounced rainy seasons, the short rains March-May and the long rains August-November. The park elevation is $1100-1500$ m.a.s.l., decreasing from north to south, which accompanies a decrease in rainfall and increase in temperature (Struhsaker, 1997).

Kibale has had some form of protection since 1932 (Baranga, 1991; Osmaston, 1959; Struhsaker, 1997), however, during the 1970s and 1980s illegal agricultural encroachment and deforestation took place in the southern part of the park (Chapman and Lambert, 2000), with $\sim 90 \%$ of this area having undergone some form of encroachment by the 1990s (Baranga, 1991; Van Orsdol, 1986), predominantly for growing subsistence crops including banana (Musa sp.), cassava (Manihot esculenta) and maize (Zea mays) and the removal of timber for fuel wood (Chapman and Lambert, 2000). In 1993, the area that now forms Kibale was given national park status. An estimated $10,000-40,000$ people living in the southern part of the park at this time were resettled outside the park boundary (Baranga, 1991; Chapman and Lambert, 2000; Van Orsdol, 1986).

The southern part of Kibale quickly became dominated by elephant grass (Pennisetum purpureum), due to repeated fires spreading from nearby subsistence farms or being set by poachers. Elephant grass can grow up to $5 \mathrm{~m}$ tall, severely inhibiting natural regeneration of native forest (UWA-FACE, 2011). In 1995 the UWAFACE Natural High Forest Rehabilitation Project was initiated, a joint forest restoration project between the Uganda Wildlife Authority and FACE the future, an independent Dutch organization that aims to mitigate climate change via sustainable forest management.

The project aimed to replant of 10,000 ha of degraded habitat with native tree species, to improve biodiversity and ecological functions, whilst also producing carbon credits established via monitoring and verification of the replanted areas. By mid-2014 some 3500 ha have been replanted.

\subsection{Forest restoration}

Restoration consisted of protection from fire (creation and maintenance of $10 \mathrm{~m}$ fire breaks; staffed fire towers for monitoring) and planting areas with native seedlings ( $400 \mathrm{ha}^{-1}$ ). Seedlings were collected from surrounding forest and raised in a nursery, under partial shade, using local forest soil, without the addition 


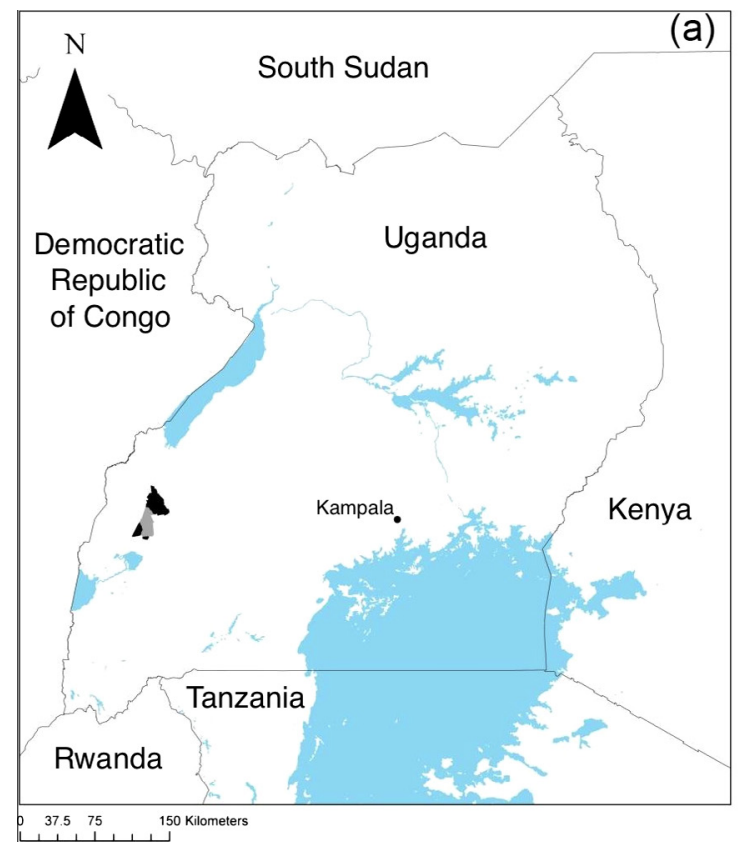

(a)

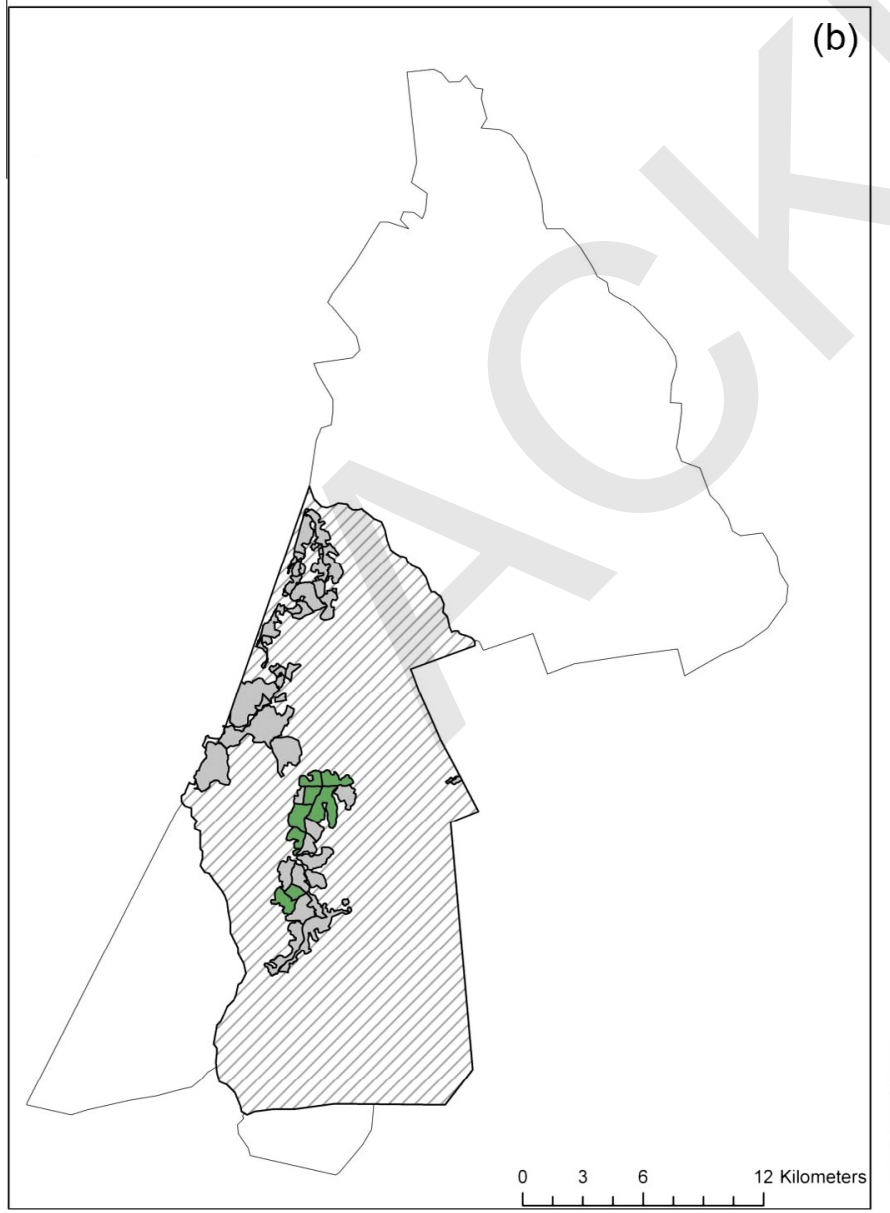

UWA-FACE project

Kibale National Park

Country border

Water

(b)

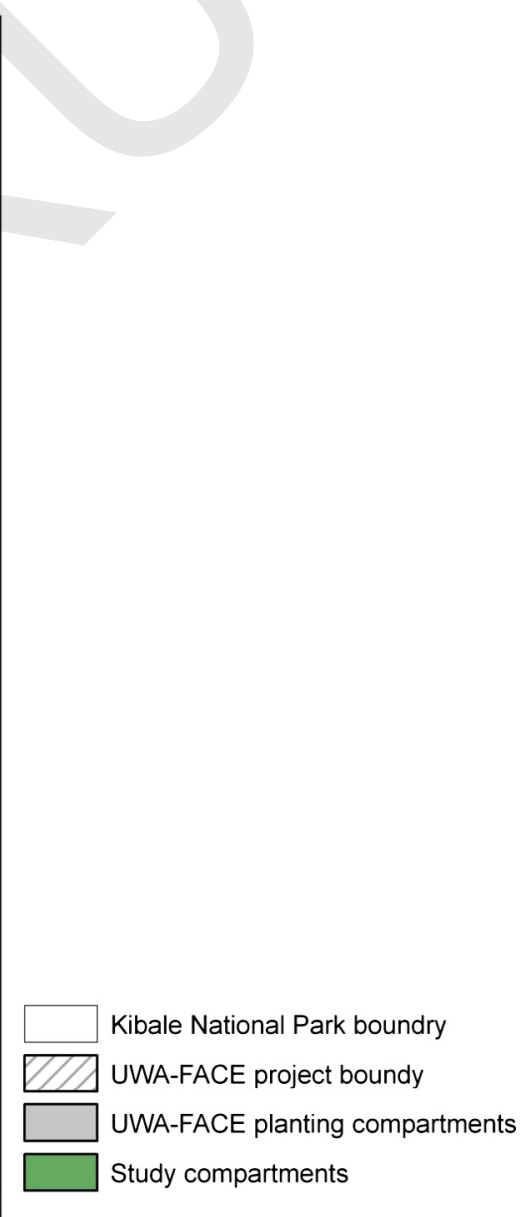

Fig. 1. Map showing location of (a) Kibale National Park within Uganda, and (b) the location of the UWA-FACE project area within Kibale and the planting compartments measured in this study.

of fertilizer (UWA-FACE, 2011). Seedlings of 0.35-1 m tall were planted every $5 \mathrm{~m}$ in a grid, unless an existing natural regenerating seedling occurred, when no seedling was planted. Of the 400 planting locations per ha, 30 , or $7.5 \%$, had an existing natural regeneration, all grasses were removed surrounding these stems and therefore they were treated as planted individuals in analysis as they were given a competitive advantage over other naturally regenerating stems. Prior to planting elephant grasses were cut 
at ground level in $2 \mathrm{~m}$ wide planting lines to reduce competition. For five years following planting, any grasses regrowing along planting lines were cut quarterly, until planted stems were $>2 \mathrm{~m}$ tall. After five years planted areas were left unmanaged, with the exception that fires were excluded.

All areas monitored in this study were located in the Phase one area, which was the first area to be planted, between 1995 and 1997. Thirty-nine species of native tree were planted; the most common were Markhamia platycalyx (Bignoniaceae), Uvariopsis congensis (Annonaceae), Prunus africana (Rosaceae), Lavoa brownii (Meliaceae), and Mimusops bagshawei (Sapotaceae), see Appendix 1 and 2 for full list of species planted per compartment and planted species observed in 2013 within sample plots.

\subsection{Plot-based study sample design}

\subsubsection{Sample plots}

In 2005 , ten years after planting, 65 plots $(10 \times 50 \mathrm{~m}, 3.25 \mathrm{ha})$ were established and measured by two of the researchers on the project reported here (Omeja et al., 2011a,b). Between 27th August and 8th December 2013, we remeasured 50 of these plots (2.5 ha), to assess changes over 18 years. No sampled plots underwent burning since restoration in 1995 . Here we reanalyse the 2005 census data (Omeja et al., 2011a) and the new 2013 census data.

We also measured 20 plots $(10 \times 50 \mathrm{~m}$, Total $=1 \mathrm{ha})$, across Kibale in old-growth forest to make comparisons with restoration forest. Old-growth plots were located in existing permanent sample plots (established by C. Chapman in 1989). A further six plots were established in grassland within the UWA-FACE project boundary. This area was originally forest, and underwent the same disturbance as restoration areas, however since abandonment in 1992 it has yet to receive any management. Therefore, we consider it representative of the area immediately before planting. Within this areas grassland plots were located at random but a minimum of $100 \mathrm{~m}$ from the grassland edge and each plot was separated by a minimum distance of $300 \mathrm{~m}$.

\subsubsection{Sampling within plots}

Within each 0.05 ha plot area for all stems $\geqslant 10 \mathrm{~cm}$ DHB (diameter at breast height) we recorded: DBH, species, height, location, and whether the stem was planted or naturally regenerating. DBH was measured at $1.3 \mathrm{~m}$ along the stem, except in the case of buttress roots or deformities, which were measured $50 \mathrm{~cm}$ above the buttress or $2 \mathrm{~cm}$ below the deformity respectively (Phillips et al., 2009). The height of every individual was measured using a handheld clinometer. Individuals were identified to species level were possible. In 2013, all stems $>1$ and $<10 \mathrm{~cm}$ DBH were measured in three $5 \times 5 \mathrm{~m}$ subplots (Fig. 2), recording $\mathrm{DBH}$, height, and species for each individual. This data was not collected in 2005. In both 2005 and 2013 ten $1 \times 1 \mathrm{~m}$ subplots were established through the centre of the plot at $5 \mathrm{~m}$ intervals for the sampling of seedlings and saplings (Fig. 2). Every seedling (i.e. $<1 \mathrm{~m}$ tall) and sapling (1-1.99 $\mathrm{m}$ tall) was identified to species and the height recorded. Additionally, the percentage cover of grasses, shrubs, seedlings, and bare ground within each $1 \mathrm{~m}^{2}$ subplot was estimated and dominant species identified The mortality of planted stems between 1995 and 2013, was calculated (Sheil and May, 1996) as;

Mortality $(\lambda)=\frac{\operatorname{Ln}\left(\text { Stems } t_{0}\right)-\operatorname{Ln}\left(\text { Stems } t_{2}\right)}{\text { Time }(\text { years })}$

where $\lambda=$ instantaneous rate of change (i.e., Percentage mortality per year), $t_{0}=$ number of trees at time 0 and $t_{2}=$ number of trees at second time interval. In each of the six grassland plots three $1 \mathrm{~m}^{2}$ samples of grasses were collected (Fig. 2), dried to constant
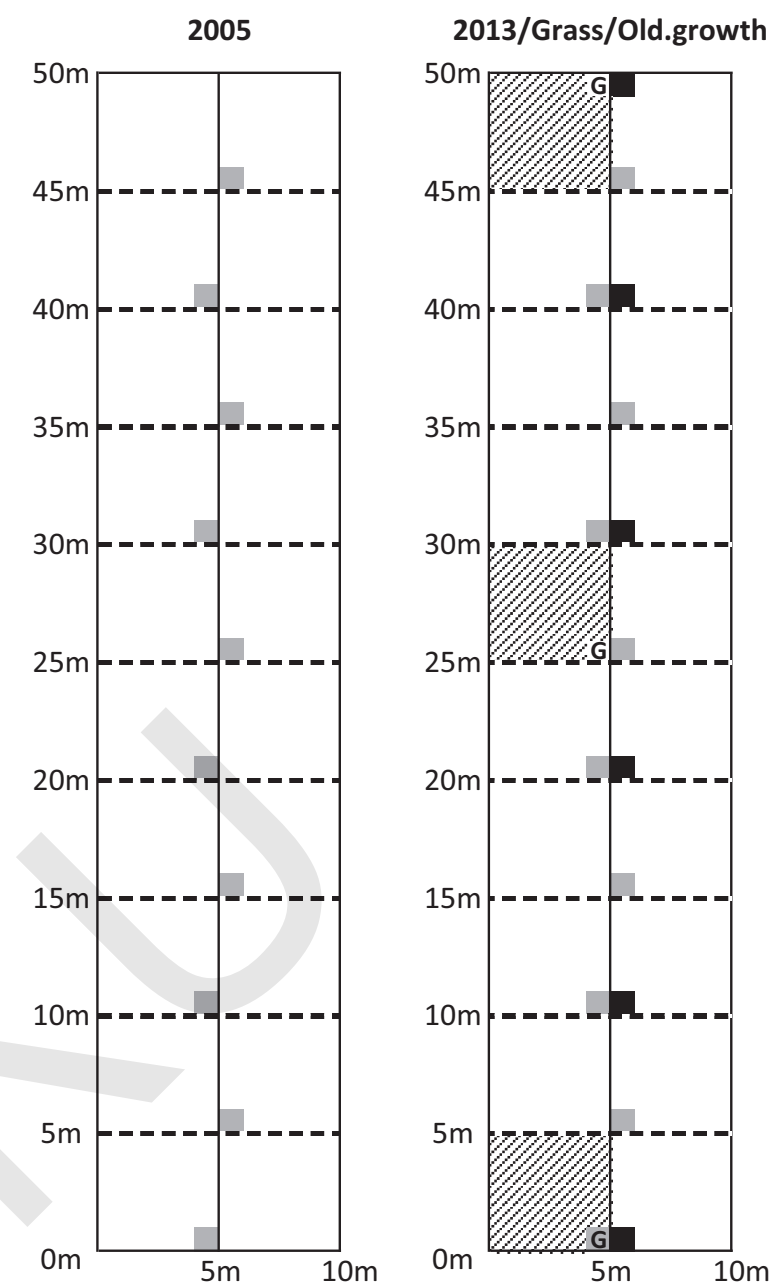

Fig. 2. Sample plot layout in restoration forest (2005, Left) and in restoration forest (2013), grassland and old-growth forest (Right). Trees $\geqslant 10 \mathrm{~cm}$ DBH measured across $10 \times 50 \mathrm{~m}$ plot, grey hashed area = trees $1<10 \mathrm{~m}$ DBH measured, grey shaded area = seedlings, $\%$ ground cover measured. Black area $=$ hemispherical photograph point, $\mathrm{G}=$ grass sampling point (grassland plots only).

mass and weighed to obtain the baseline above ground biomass of grasses prior to planting.

\subsubsection{Leaf area index}

Hemispherical photographs were taken at $10 \mathrm{~m}$ intervals along the centre of the plot ( $n=6$, Fig. 2 ) to estimate leaf area index (LAI) and percentage canopy cover ( $8 \mathrm{~mm}$ F3.5 EX DG Fisheye Sigma lens; Canon 350d SLR camera; CAN-EYE V6.1 software). All six photographs from a single plot were processed together producing a mean LAI per plot, using an angular resolution of $2.5^{\circ}$ in both Zenith $(\theta)$ and Azimuth $(\varphi)$ directions. A view zenith angle of $0-$ $60^{\circ}$ was selected as it is a high enough resolution to extract canopy gaps of $<6 \mathrm{~cm}$ (Leblanc et al., 2005), whilst also removing the extreme edges of the images that are dominated by woody material such as trunks so not required for LAI estimation. No hemispherical photographs were taken in 2005.

\subsubsection{Data analysis}

2.3.4.1. Biomass and height. Aboveground biomass, in Mg dry mass $\mathrm{ha}^{-1}$ ( $1 \mathrm{Mg}=1$ metric ton) was calculated as:

$\mathrm{AGB}=0.0673 \times\left(\rho D^{2} H\right)^{0.976}$

where $\rho=$ wood density, $D=\mathrm{DBH}$ and $H=$ height (Chave et al., 2014). Wood density values for each species were obtained from 
the global wood density database (Chave et al., 2006; Zanne et al., 2009) available from the Dryad data repository (http://datadryad. $\operatorname{org} /$ ). Where species-specific wood densities were not available, genus mean ( $n=32$ species) or familial mean ( $n=5$ species) wood densities were used (Lewis et al., 2009). If family was unknown then the mean plot wood density was used ( $n=5$ individuals, see Appendix 3 for full species list).

Two structural parameters were analysed: First, the asymptotic height of trees in all parameter asymptotic model of the form: $y=a$ $\left(1-\exp ^{(-b x)}\right)$, was found to be the best fit to the data for all three habitats. (Restoration forest in 2005 and 2013 and old-growth forest, Fig. S1.) Secondly, we analysed the size frequency distribution of stems using doubling size classes $(1-2 \mathrm{~cm}, 2-4 \mathrm{~cm} . .64-$ $128 \mathrm{~cm}$ ) to account for the exponential decrease in stems as DBH increases, with the expectation that old-growth forest will exhibit an inverse-J shaped distribution (Kohyama, 1986). Additionally, we assess the wood density of trees. Wood density (WD) is a readily available plant species trait that is correlated with growth and mortality and has been related to shade tolerance of tropical forest species (Philipson et al., 2014; Whitmore, 1998). In the high light environment of the restoration area, shade tolerance is likely to be an important factor in determining the survival of planted species, therefore we compare the WD of species that were planted, survived and died using ANOVA.

2.3.4.2. Biodiversity. Alpha diversity of trees ( $\geqslant 10 \mathrm{~cm} D B H)$ and seedlings was assessed using Hill numbers, which describe biodiversity along a continuous scale from species richness to species evenness (Hill, 1973). We report Hill numbers at the extremes, $N_{0}=$ species richness and $N_{2}=$ inverse of Simpsons $D$ index (or species evenness). Differences in $\alpha$ diversity were compared among habitats using analysis of variance and Tukey's HSD tests. The species composition of different habitats was compared using non-metric multidimensional scaling (NMDS), which shows dissimilarity plots and species (Lepš and Šmilauer, 2003). Biodiversity and NMDS analysis used the Vegan package (Oksanen et al., 2013) in $\mathrm{R}$ ( $\mathrm{R}$ Core Team, 2013).

\section{Results}

\subsection{Forest structure and biomass}

\subsubsection{Grassland}

In grassland plots, which are representative of the area prior to restoration, there were no trees $\geqslant 10 \mathrm{~cm}$ DBH. Total AGB was $5.1 \mathrm{Mg} \mathrm{ha}^{-1}( \pm 1,95 \% \mathrm{CI})$, of which $4.1 \mathrm{Mg} \mathrm{ha}^{-1}$ (80\%) was elephant grass and $1 \mathrm{Mg} \mathrm{ha}^{-1}$ was saplings $<10 \mathrm{~cm} \mathrm{DBH}$. Grasses dominated ground cover $(66 \%, \pm 5)$, with some shrubs $(15 \%, \pm 4)$ and very low seedlings cover of $1 \%( \pm 0.6)$. Stems between 1 and $10 \mathrm{~cm} \mathrm{DBH}$ had a density of $1733( \pm 1341)$, and BA of $0.8 \mathrm{~m}^{2} \mathrm{ha}^{-1}( \pm 0.6)$. Canopy cover was low at $20 \%( \pm 10)$, with an LAI of $1.4( \pm 0.5)$.

\subsubsection{Replanted forest 10 years after planting}

In the restoration area, ten years after planting (in 2005) the density of stems $\geqslant 10 \mathrm{~cm}$ DBH had increased to 130 stems ha $^{-1}$ $( \pm 21)$, with an AGB of $9.5 \mathrm{Mg} \mathrm{ha}^{-1}( \pm 2.9)$ a basal area of $2.4 \mathrm{~m}^{2} \mathrm{ha}^{-1}( \pm 0.5)$ and a wood density of $0.57 \mathrm{~g} \mathrm{~cm}^{3}( \pm 0.02)$. With most stems and AGB being found in the $8-16 \mathrm{~cm}$ size class (Fig. 3). The canopy was still relatively short with an asymptotic canopy height of $11 \mathrm{~m}( \pm 0.6)$. The percentage cover of grasses had more than halved in the ten years since planting to $31 \%( \pm 2)$, with elephant grass ( $P$. purpureum) still being the most common species, found in $35 \%$ of plots. Meanwhile shrub ground cover doubled to $32 \%$ ( \pm 2 ) with Lantana camara being the most common shrub found in $36 \%$ of plots. Seedling cover increased fivefold to $5 \%( \pm 1)$.

\subsubsection{Replanted forest 18 years after planting}

In the second census of the restoration plots in 2013, stem density $(\geqslant 10 \mathrm{~cm} \quad \mathrm{DBH})$ and $\mathrm{BA}$ increased significantly to 349 stems ha ${ }^{-1}( \pm 43)$ and $8.8 \mathrm{~m}^{2} \mathrm{ha}^{-1}( \pm 1.4)$, respectively (stems $p=<0.001$, BA $p=<0.001)$. AGB increased by $29 \mathrm{Mg} \mathrm{ha}^{-1}$, to $40.6 \mathrm{Mg} \mathrm{ha}^{-1}( \pm 7.7)$, but not significantly so $(p=0.19)$. There was no change in wood density $\left(0.57 \mathrm{~g} \mathrm{~cm}^{3} \pm 0.01\right)$. Whilst there were more stems between 8 and $16 \mathrm{~cm} \mathrm{DBH,} 50 \%$ of AGB was stored in stems between 16 and $32 \mathrm{~cm}$ DBH (Fig. 3). Asymptotic canopy height had increased to $15 \mathrm{~m}( \pm 1)$. The addition of stems between 1 and $10 \mathrm{~cm} \mathrm{DBH}$ added a further 8358 stems ha $^{-1}( \pm 2880)$, $10 \mathrm{Mg} \mathrm{ha}^{-1}( \pm 1.5)$ AGB and $5.4 \mathrm{~m}^{2} \mathrm{ha}^{-1}( \pm 0.7)$ of BA.

The percentage cover of grasses had decreased further to $19 \%$ $( \pm 2)$. More importantly, the species composition of grasses changed dramatically, with an unidentified species, local name Panicum, becoming the most common species, found in $41 \%$ of plots whereas, elephant grass was found in just $4 \%$ of plots. Panicum appears not to compete so effectively with seedlings and saplings, growing to a maximum of $10 \mathrm{~cm}$, and was also present in $12 \%$ of old-growth forest plots. Shrub cover increased to $44 \%( \pm 3)$, dominated by the invasive species L. camara. There was no change in seedling cover. In the 18 years since planting, canopy cover increased considerably from $20 \%$ to $73 \%( \pm 5)$, with an LAI of 4.5 $( \pm 0.3)$.

\subsubsection{Old-growth forest}

In old-growth forest stem density ( $\geqslant 10 \mathrm{~cm} \mathrm{DBH}$,) was not significantly greater than seen in restoration plots in 2013 $(p=0.13)$, at 413 stems ha ${ }^{-1}( \pm 66)$. However, AGB, BA and wood density were all significantly larger than in restoration forest at $415 \mathrm{Mg} \mathrm{ha}^{-1}( \pm 111, p=<0.001), 34 \mathrm{~m}^{2} \mathrm{ha}^{-1}( \pm 5, p=<0.001)$, and $0.62 \mathrm{~g} \mathrm{~cm}^{3}( \pm 0.02, p=0.003)$, respectively. The frequency distribution of stems is a typical inverse-J shape (Fig. 3). There is a much higher density of stems $>32 \mathrm{~cm}$ DBH compared to restoration forest after 18 years, with $85 \%$ of AGB found in stems $\geqslant 32 \mathrm{~cm} \mathrm{DBH}$ and $55 \%$ of AGB in stems $\geqslant 64 \mathrm{~cm} \mathrm{DBH}$ (Fig. 3), and taller asymptotic canopy height at $47 \mathrm{~m}( \pm 5)$. Stems between 1 and $10 \mathrm{~cm}$ DBH comprise $6400 \mathrm{ha}^{-1}( \pm 2211), 12.6 \mathrm{Mg} \mathrm{ha}^{-1}( \pm 2.9)$ of AGB and $4.9 \mathrm{~m}^{2} \mathrm{ha}^{-1}( \pm 0.9)$ of BA. The percentage cover of grasses and shrubs was not different $(22 \% \pm 3)$, seedling cover was higher, $(12 \% \pm 1)$, and canopy cover was higher, than seen in restoration forest $(92 \% \pm 2.7 ; \mathrm{LAI}=6.3 \pm 0.2)$.

\subsubsection{Biomass accumulation}

Eighteen years after planting the AGB of restoration forest equates to $12 \%$ of old-growth AGB. The initial net AGB accumulation rate during the first ten years after planting of stems $\geqslant 10 \mathrm{~cm}$ DBH was slow, at $0.95 \mathrm{Mg} \mathrm{ha}^{-1} \mathrm{y}^{-1}$. However, between 10 and 18 years after planting AGB accumulation increased to 3.9 $\mathrm{Mg} \mathrm{ha}^{-1} \mathrm{y}^{-1}$. If AGB accumulation continued at 3.9 $\mathrm{Mg} \mathrm{ha}^{-1} \mathrm{y}^{-1}$ it would take a further 96 years for restoration forest to attain oldgrowth forest AGB (i.e. total 114 years).

\subsubsection{Biomass accumulation and forest structure of planted verses non-planted trees}

In the sample plots in 1995, an average of 390 stems ha $^{-1}( \pm 20)$ were planted with an additional 30 naturally regenerating stems $\mathrm{ha}^{-1}( \pm 12)$ located at planting positions that received management, combined this is slightly higher than the $400 \mathrm{ha}^{-1}$ expected. Planted stems had an annual mortality of 3\%, leaving 153 planted stems $\mathrm{ha}^{-1}( \pm 20)$ in 2013 . In 2005, just $33 \%$ of AGB and $37 \%$ of BA of stems $>10 \mathrm{~cm}$ was stored in planted stems, despite $50 \%$ of stems being planted (Table 1). By 2013, the majority of stems $>10 \mathrm{~cm}$ were planted individuals (61\%), and most AGB (69\%) and BA (66\%) was stored in planted stems (Table 1 ). Wood density of planted and non-planted stems was not significantly different in 
Frequency Distribution
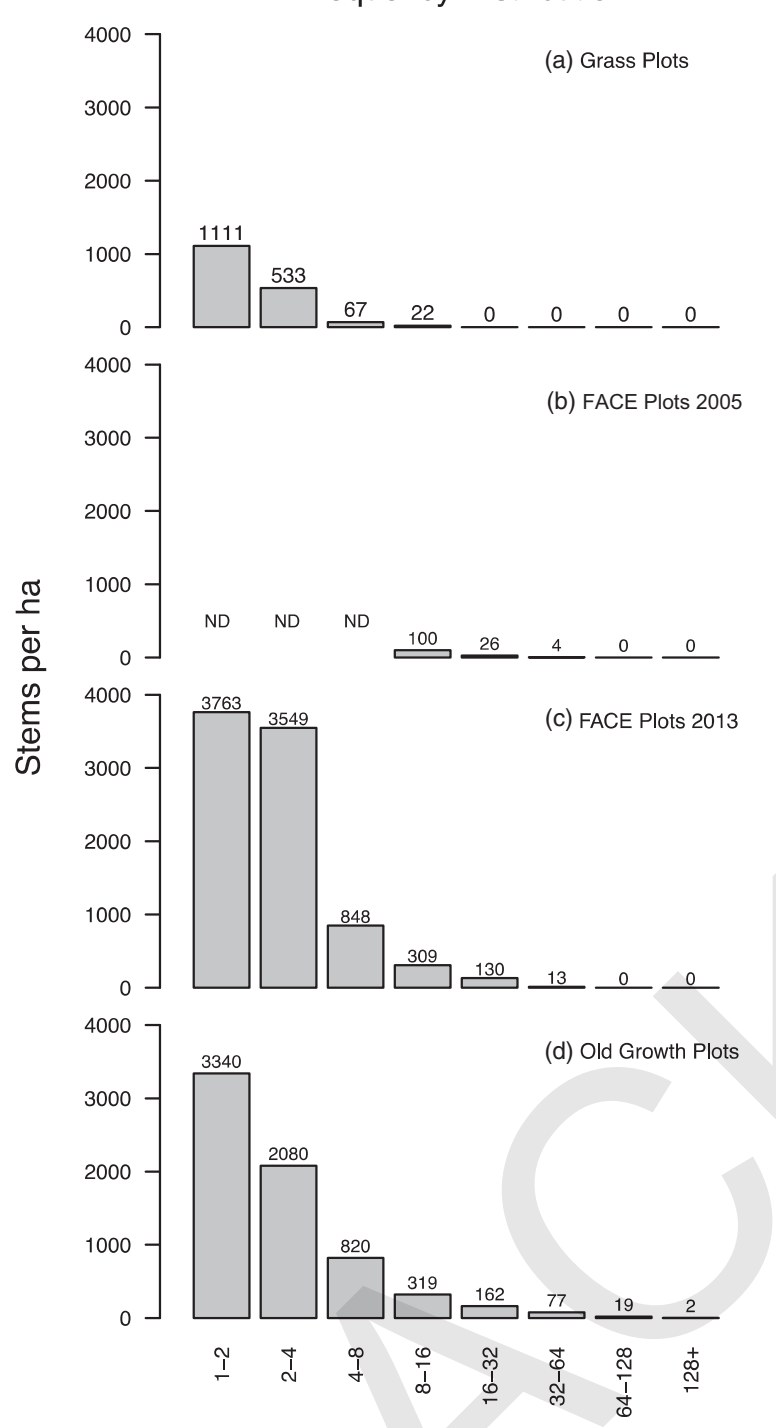

AGB Distribution
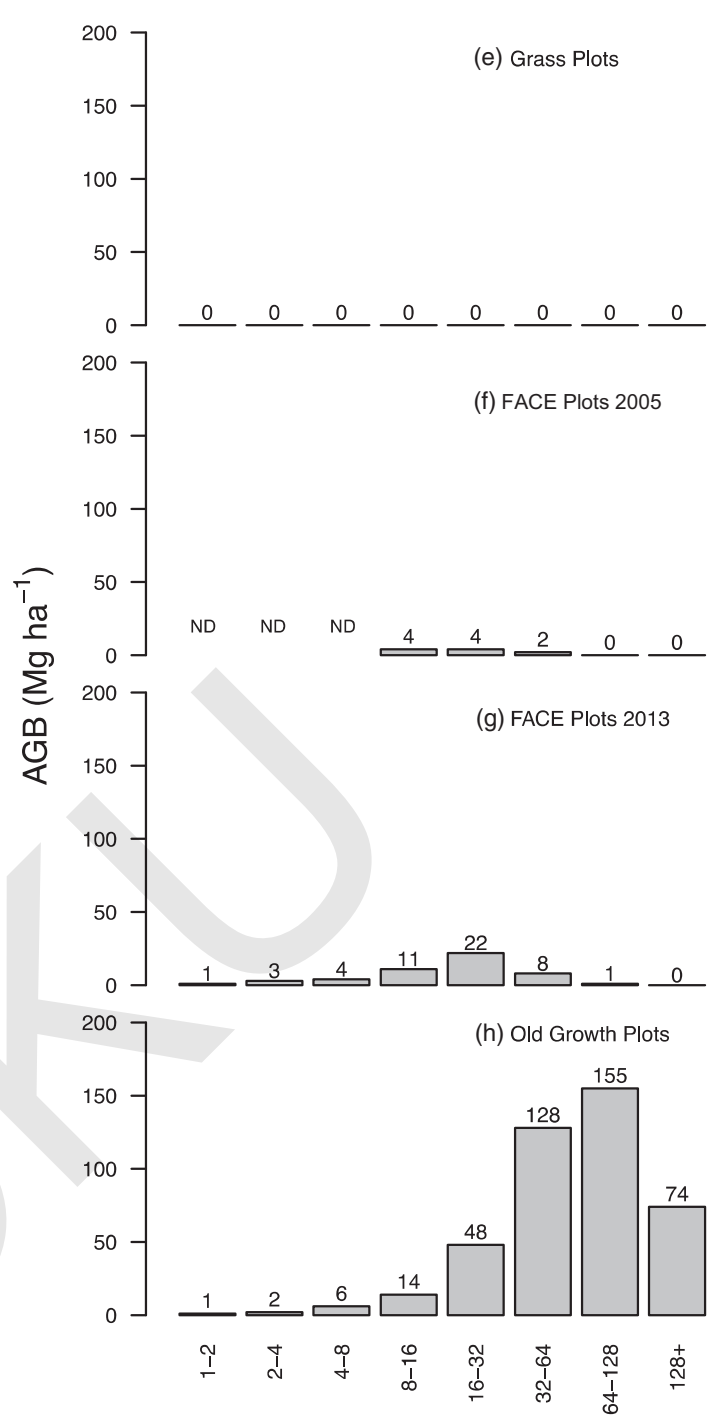

\section{Size Class (cm DBH)}

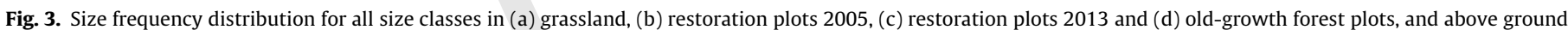

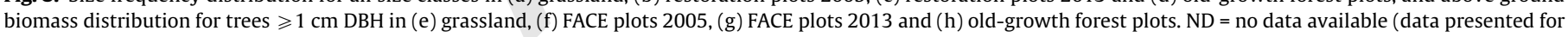
FACE plots in 2005 is only for stems $\geqslant 10 \mathrm{~cm} \mathrm{DBH}$ ).

either census (2005; $T=-1.04, \mathrm{DF}=66.2, P=0.3,2013 ; T=-1.9$, $\mathrm{DF}=95, P=0.07)$, with planted stems having slightly high WD (Table 1). The recruitment of planted stems $\geqslant 10 \mathrm{~cm}$ was almost double that of non-planted stems $(T=-2.6, D F=98, P=0.009)$, and the AGB accumulation rate of planted stems is significantly higher than seen in non-planted stems $(T=-6.2, D F=71$, $P=<0.0001$, Table 1$)$. Thus, it appears that the planted stems are becoming increasingly dominant as the forest matures.

\subsubsection{Biomass and structure of different planted tree species}

In 1995 a total of 39 species were planted, which had a mean WD of $0.60 \mathrm{~g} \mathrm{~cm}^{3}( \pm 0.01)$. The most common species, which each constituted $>10 \%$ of originally planted stems were; $U$. congensis, Markhamia lutea, M. bagshawei and P. africana (Table 2). These dominant planted species had a mean WD of $0.61 \mathrm{~g} \mathrm{~cm}^{3}( \pm 0.1)$. Eighteen years after planting, within the area sampled, these same four species each made up $<5 \%$ of surviving planted stems (Table 2 ), with just two individuals of $U$. congensis, seven M. lutea, 12 M. bagshawei, and 17 P. africana being observed. Despite only a small proportion of the planted area being sampled, this low encounter rate of the most commonly planted species suggests they have a poor survival rate.

Ten years after planting, in 2005, seven species of planted tree $\geqslant 10 \mathrm{~cm}$ DBH were observed, of these just three (Bridelia micrantha, Warbugia ugandensis, and Sapium ellipticum) made up $>95 \%$ of planted stem density, AGB and BA (Table 3). Thus, the third most important 'planted' species is S. ellipticum, which is actually naturally regenerating with the addition of grass management. This suggests, with the exception of $B$. micrantha and $W$. ugandensis many planted species have poor survival rates. By 2013 an additional eight species of planted tree $\geqslant 10 \mathrm{~cm}$ DBH were observed, with the same three species still dominating (Table 3). By 2013, B. micrantha was by far the most common planted species, making up $62 \%$ of planted stems, however it contributed just 33\% of AGB (Table 3). This is due to its small size, in terms of mean DBH and height (Table 3). W. ugandensis, by contrast contributed $55 \%$ of planted AGB, despite making up $<30 \%$ of planted stems (Table 3 ), as $W$. ugandensis is a much larger species than $B$. micrantha 
Table 1

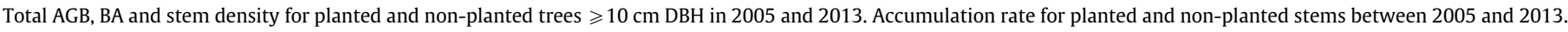
$95 \% \mathrm{CI}$ in parentheses.

\begin{tabular}{|c|c|c|c|c|}
\hline & & 2005 & 2013 & Accumulation $\left(\mathrm{y}^{-1}\right)$ \\
\hline Above ground biomass $\left(\mathrm{Mg} \mathrm{ha}^{-1}\right)$ & $\begin{array}{l}\text { Planted } \\
\text { Non-planted }\end{array}$ & $\begin{array}{l}3.3(1.1) \\
6.6(2.9)\end{array}$ & $\begin{array}{l}28.2(5.6) \\
12.4(3.3)\end{array}$ & $\begin{array}{l}3.1(0.7) \\
0.7(0.3)\end{array}$ \\
\hline Basal area $\left(\mathrm{m}^{2} \mathrm{ha}^{-1}\right)$ & $\begin{array}{l}\text { Planted } \\
\text { Non-planted }\end{array}$ & $\begin{array}{l}0.9(0.2) \\
1.5(0.5)\end{array}$ & $\begin{array}{l}5.2(0.9) \\
3.7(1.0)\end{array}$ & $\begin{array}{l}0.5(0.1) \\
0.3(0.1)\end{array}$ \\
\hline Stem density $\left(\geqslant 10 \mathrm{~cm} \mathrm{DBH} \mathrm{ha}^{-1}\right)$ & $\begin{array}{l}\text { Planted } \\
\text { Non-planted }\end{array}$ & $\begin{array}{l}62(12) \\
61(15)\end{array}$ & $\begin{array}{l}206(34) \\
144(29)\end{array}$ & $\begin{array}{l}18(4) \\
10(3)\end{array}$ \\
\hline Wood density $\left(\mathrm{g} \mathrm{cm}^{3}\right)$ & $\begin{array}{l}\text { Planted } \\
\text { Non-planted }\end{array}$ & $\begin{array}{l}0.59(0.02) \\
0.56(0.04)\end{array}$ & $\begin{array}{l}0.58(0.02) \\
0.56(0.02)\end{array}$ & $\begin{array}{l}- \\
-\end{array}$ \\
\hline
\end{tabular}

Table 2

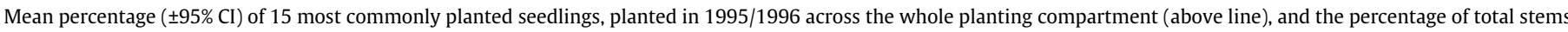

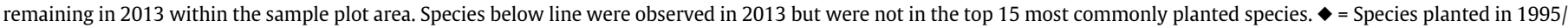
1996 but not observed in 2013.

\begin{tabular}{|c|c|c|}
\hline & $\begin{array}{l}1995 / 1996 \\
\% \text { of all seedlings planted }\end{array}$ & $\begin{array}{l}2013 \\
\% \text { of all planted trees } \geqslant 1 \mathrm{~cm} \mathrm{DBH}\end{array}$ \\
\hline Markhamia platycalyx & $15.1(3.4)$ & $1.5(2.6)$ \\
\hline Uvariopsis congensis & $13.7(5.2)$ & $0.4(0.5)$ \\
\hline Prunus africana & $11.6(5.5)$ & $3.3(3.2)$ \\
\hline Mimusops bagshawei & $10.4(5.7)$ & $3.3(4.9)$ \\
\hline Lovoa brownii & $8.7(4.5)$ & $\bullet$ \\
\hline Chrysophyllum albidum & $4.4(2.4)$ & $\bullet$ \\
\hline Blighia wildmaniana & $4.4(1.6)$ & $0.2(0.4)$ \\
\hline Warbugia ugandensis & $4.6(3.8)$ & $25(6.4)$ \\
\hline Strombosia scheffleri & $3.0(1.4)$ & $\bullet$ \\
\hline Albizia gummifera & $2.6(2.0)$ & $0.3(0.5)$ \\
\hline Bridelia micrantha & $2.9(4.4)$ & $54.4(14)$ \\
\hline Diospyros mespiliformis & $3.2(2.8)$ & $0.6(1.2)$ \\
\hline Antiaris toxicaria & $1.7(1.2)$ & $\bullet$ \\
\hline Spathodea campanulata & $1.9(1.3)$ & $0.4(0.8)$ \\
\hline Pancovia turbinata & $1.7(0.8)$ & $\bullet$ \\
\hline Celtis durandii & $1.0(0.8)$ & $0.2(0.3)$ \\
\hline Tabernaemontana holstii & $0.5(1.1)$ & $1.9(2.5)$ \\
\hline Sapium ellipticum ${ }^{\mathrm{a}}$ & & $6.5(3.8)$ \\
\hline Croton macrostachyus & & $1.6(2.0)$ \\
\hline Allophyllus rubifolius ${ }^{\mathrm{a}}$ & & $0.4(0.7)$ \\
\hline
\end{tabular}

a Species were natural regenerating stems in 1995/1996 that received management of grasses, management of grasses.

Table 3

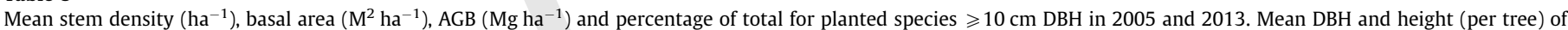
planted species in 2005 and 2013. 95\% CI in parentheses.

\begin{tabular}{|c|c|c|c|c|c|c|c|c|c|}
\hline & & \multicolumn{2}{|c|}{ Stems (per ha) } & \multicolumn{2}{|c|}{ Basal area $\left(\mathrm{M}^{2} \mathrm{ha}^{-1}\right)$} & \multicolumn{2}{|c|}{ AGB $\left(\mathrm{Mg} \mathrm{ha}^{-1}\right)$} & \multirow{2}{*}{$\begin{array}{l}\text { Average DBH }(\mathrm{cm}) \\
\text { Mean }\end{array}$} & \multirow{2}{*}{$\begin{array}{l}\text { Average Height (m) } \\
\text { Mean }\end{array}$} \\
\hline & & Mean & $\%$ & Mean & $\%$ & Mean & $\%$ & & \\
\hline \multirow[t]{2}{*}{ B. micrantha } & 2005 & $36(12)$ & 57.1 & $0.5(0.2)$ & 53.7 & $1.3(0.8)$ & 46.2 & $12.3(0.6)$ & $7.4(0.6)$ \\
\hline & 2013 & $128(36)$ & 62 & $2.5(0.8)$ & 48.1 & $7.5(2.7)$ & 33.4 & $15.1(0.8)$ & $8.6(0.6)$ \\
\hline \multirow[t]{2}{*}{ W. ugandensis } & 2005 & $23(8)$ & 36.5 & $0.3(0.1)$ & 38.1 & $1.3(0.5)$ & 44.4 & $13.2(0.6)$ & $8.4(0.4)$ \\
\hline & 2013 & $55(13)$ & 26.7 & $2.2(0.6)$ & 41.9 & $12.9(3.8)$ & 57.8 & $21.7(1.7)$ & $12.1(0.6)$ \\
\hline \multirow[t]{2}{*}{ S. ellipticum ${ }^{\mathrm{a}}$} & 2005 & $2(2)$ & 3.2 & $0.04(0.04)$ & 4.3 & $0.1(0.2)$ & 4.6 & $15.8(0.9)$ & $9.2(1.5)$ \\
\hline & 2013 & $11(7)$ & 5.3 & $0.3(0.2)$ & 5.6 & $1.2(0.8)$ & 5.2 & $18.2(1.4)$ & $10.4(0.6)$ \\
\hline \multirow[t]{2}{*}{ Other } & 2005 & $2(2)$ & 3.2 & $0.03(0.03)$ & 3.9 & $0.1(0.1)$ & 4.8 & $14.4(0.9)$ & $10.3(0.6)$ \\
\hline & 2013 & $12(8)$ & 6 & $0.2(0.1)$ & 4.4 & $0.8(0.5)$ & 3.6 & $22.1(2.9)$ & $14(2.1)$ \\
\hline
\end{tabular}

a S. ellipticum were natural regenerating stems that received management of grasses, only species with $\geqslant 5$ individuals sampled shown.

(Table 3). Of the naturally regenerating stems S. ellipticum and $B$. micrantha were the most common species making up 35\% and $23 \%$ of individuals, respectively. See Appendix 4 for full list of naturally regenerating species.

Within sample plots the WD of planted species that survived until 2013 was $0.57 \mathrm{~g} \mathrm{~cm}^{3}( \pm 0.2)$, significantly lower than the WD of originally planted species $(T=2.8, \mathrm{DF}=14, P=0.01)$. This could suggest that lower WD species, which may favour the higher light conditions found in restoration areas at the time of planting, have better survival. However the survival and growth of species is liable o change over the coming years as LAI and canopy cover increase, which would favour more shade tolerant specie.

\subsection{Biodiversity and species composition}

Species richness $\left(N_{0}\right)$ is lowest in grassland with no trees $\geqslant 10 \mathrm{~cm}$ DBH and just two seedling species per 0.05 ha plot. As time after planting increases, so too does biodiversity, with 
Table 4

Hill numbers $N_{0}$, and $N_{2}$ for grassland plots, restoration plots 2005 , restoration plots 2013 and old-growth plots for trees $\geqslant 10 \mathrm{~cm}$ DBH and seedlings $\leqslant 1 \mathrm{~m}$. Plot $=0.05$ ha.

\begin{tabular}{|c|c|c|c|}
\hline & Habitat & $\begin{array}{l}N_{0} \\
\text { Species richness }\end{array}$ & $\begin{array}{l}N_{2} \\
\text { Inverse Simpsons } D\end{array}$ \\
\hline Trees $(\geqslant 10 \mathrm{~cm} \mathrm{DBH})$ & $\begin{array}{l}\text { Grass } \\
\text { Restoration } 2005 \\
\text { Restoration } 2013 \\
\text { Old-growth }\end{array}$ & $\begin{array}{l}0 \\
2.7(0.3) \\
4.9(0.6) \\
8.3(1.4)\end{array}$ & $\begin{array}{l}0 \\
2.2(0.2) \\
2.9(0.4) \\
4.8(0.9)\end{array}$ \\
\hline Seedlings $(\leqslant 1 \mathrm{~m})$ & $\begin{array}{l}\text { Grass } \\
\text { Restoration } 2005 \\
\text { Restoration } 2013 \\
\text { Old-growth }\end{array}$ & $\begin{array}{r}1.7(1.1) \\
2.5(0.9) \\
8.5(0.7) \\
15.8(2.6)\end{array}$ & $\begin{array}{l}1.4(1.0) \\
1.1(0.2) \\
3.7(0.5) \\
5.8(1.3)\end{array}$ \\
\hline
\end{tabular}

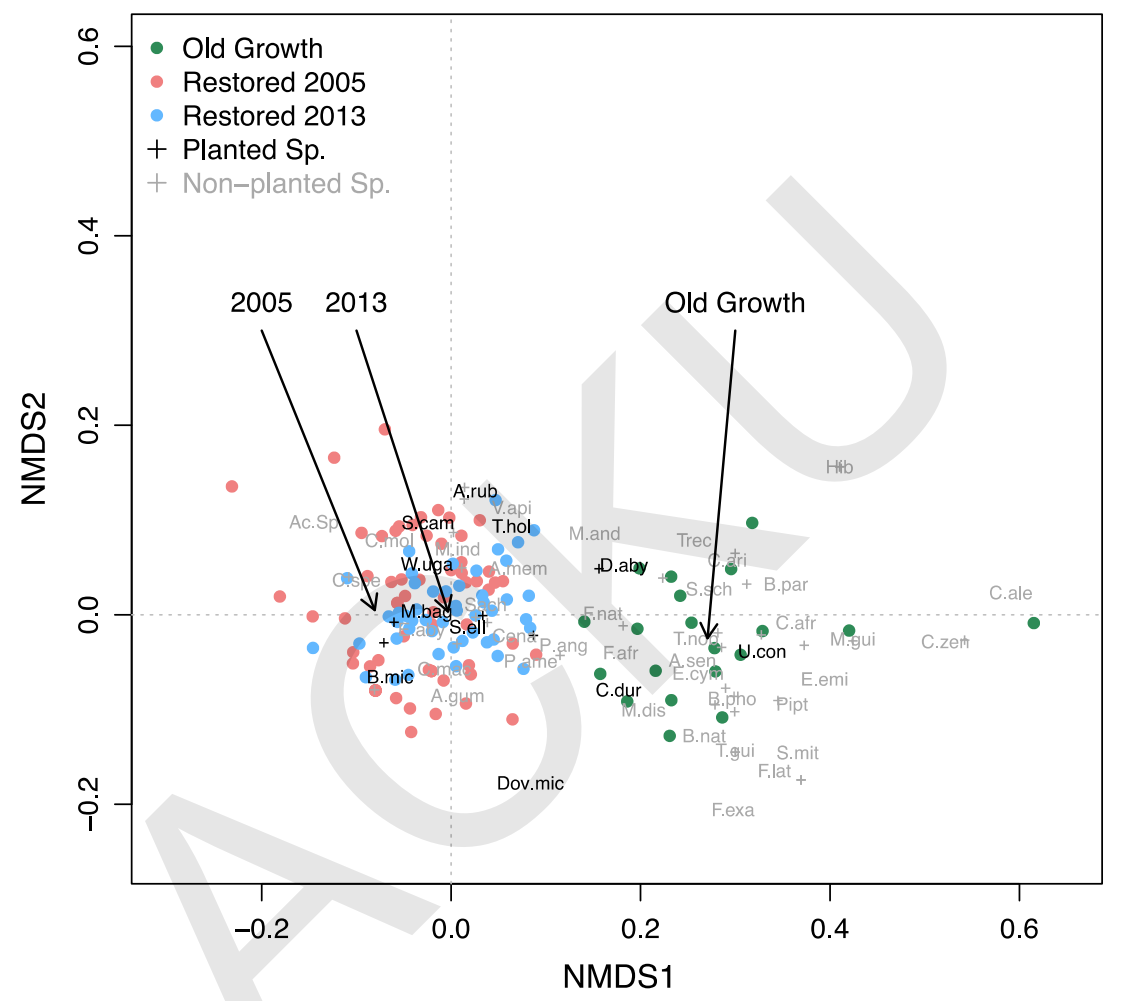

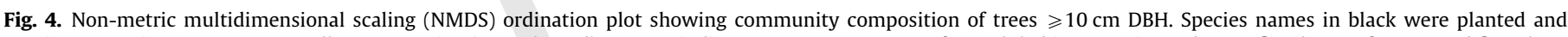

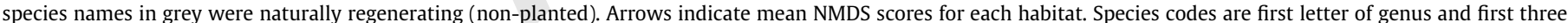

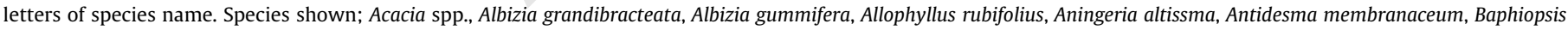

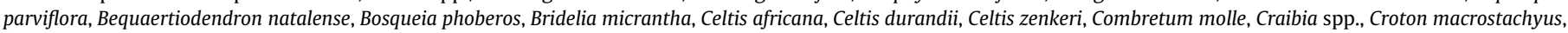

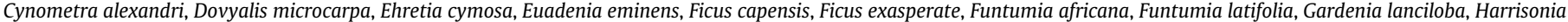

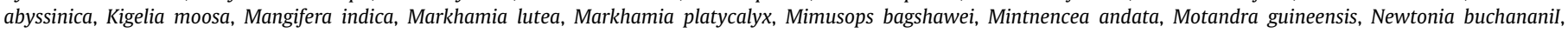

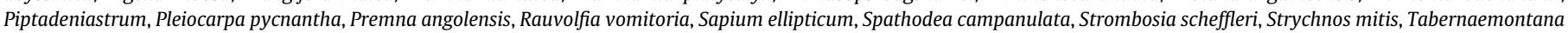
holstii, Teclea nobilis, Trichilia dregeana, Uvariopsis congensis, Vanguaoria apiculata, Warbugia ugandensis.

restoration plots in 2013 having two more tree species and six more seedling species per plot than restoration plots in 2005 (Table 4). Nevertheless, by 2013, restoration plots still have significantly fewer tree species $(t=4.3, \mathrm{DF}=26, P=0.0002)$ and seedling species $(t=5.4, \mathrm{DF}=22, P<0.0001)$, than old-growth forest, which has 8 tree and 16 seedling species per plot (Table 4 ).

Species evenness $\left(N_{2}\right)$ in stems $\geqslant 10 \mathrm{~cm}$ also increases in restoration plots between 2005 and 2013, but by very little, suggesting that 18 years after planting, a small number of species still dominate (Table 4). Seedling species evenness increases more than that of trees in restoration plots between 2005 and 2013 (Table 4). However, species evenness in restoration plots in 2013 is still significantly lower than in old-growth forest for both trees $(t=3.6, \mathrm{DF}=27, P=0.001)$ and seedlings $(t=3.6$, $\mathrm{DF}=26, P=0.001$ ).
NMDS plots showed that the community composition of trees $\geqslant 10 \mathrm{~cm}$ DBH in restoration forest and old-growth forest differ markedly. There was a clear clustering of sample plots along NMDS axis 1 , with restoration forest plots in 2005 and 2013 noticeably overlapping to the left of axis 1 and old-growth forest plots clustered to the right (Fig. 4). The mean NMDS scores in restoration forest in 2013 had shifted to the right along NMDS axis 1, which suggests that species composition was becoming more similar to old-growth forest. There was also some clustering of planted species (in black) over restoration forest plots on the left of NMDS axis 1 (Fig. 4). There were some planted species that did not overlap with restoration forest plots, notably $U$. congensis (U.con in Fig. 4), this is a species that was rarely encountered in restoration forest despite being planted, but was common in old-growth forest. 


\section{Discussion}

\subsection{Effects of active restoration on above ground biomass and carbon sequestration}

This study demonstrates that the effective restoration of this heavily degraded tropical forest site is possible using a combination of management to exclude fire plus tree planting. Above ground biomass accumulation of stems $\geqslant 10 \mathrm{~cm}$ DBH increased fourfold to $3.9 \mathrm{Mg} \mathrm{ha}^{-1} \mathrm{y}^{-1}$ between 10 and 18 years, showing significant carbon sequestration. This result shows a danger of relying on short-term studies to predict long-term accumulation of AGB in restoration forest, as early $A G B$ accumulation rates are likely to be unrepresentative of long-term trends. Indeed, using the first 10 year accumulation rate suggests it would take a further 400 years for AGB to reach old-growth levels, whereas we estimate if will take a further 96 years. The initially slow rate of AGB accumulation is likely due to two factors. Firstly, the relatively small numbers of photosynthesizing leaves on small tree seedlings means that growth is slow. Secondly, as dense elephant grass (P. purpureum) was removed ( $\left.\sim 5 \mathrm{Mg} \mathrm{ha}^{-1}\right)$, new growth from seedlings must compensate for this before there is a net AGB increase.

After 18 years restoration forest is still in the early stages of succession therefore it is uncertain how the rate of AGB accumulation will change in the future. However, we could predict that the maximum rate of $A G B$ accumulation would not exceed the rate of above-ground wood production (AGWP) seen in nearby oldgrowth forest permanent sample plots, of $6.9 \mathrm{Mg}$ dry mass ha ${ }^{-1} \mathrm{y}^{-1}$ $( \pm 1.2,95 \% \mathrm{CI}, \mathrm{C}$. Chapman, unpublished data). AGWP is calculated as the difference in AGB for stems that were present in the first and second census, plus the AGB of any new stems that appeared in the second census (Talbot et al., 2014), i.e. the new additions of woody dry mass into the forest system. Accumulation of AGB is equal to AGWP minus biomass losses due to mortality, therefore maximum AGB accumulation is likely to be lower than AGWP. However, AGWP is still considerably higher than the AGB accumulation rate calculated in this study, suggesting that increases in carbon sequestration in the restoration plots are possible.

Once the restoration forest canopy fully closes the stand will likely start to self-thin, with slower growing, shade tolerant latesuccessional species beginning to supersede the planted pioneer trees and early successional species (Finegan, 1996; Rees et al., 2001). This will create a more uneven aged stand, mimicking the recruitment and mortality dynamics seen in old-growth forest (Sheil and May, 1996). An increase in mortality will eventually lead to a reduction in overall AGB accumulation rate, at the stand level, as the stand approaches the AGB of old-growth forest (Lichstein et al., 2009).

We know of only three studies that monitored active tropical forest restoration for a period greater than 18 years, all from Australia (Catterall et al., 2012; Kanowski et al., 2003; Preece et al., 2012). However, all of these studies were forest chronosequence studies, rather than repeated measurements of permanent sample plots, and only one estimated AGB accumulation (Preece et al., 2012). Therefore, we believe our study is the longest duration study of tropical restoration using repeated sampling. Preece et al. (2012) estimated AGB accumulation of $12 \mathrm{Mg} \mathrm{ha}^{-1} \mathrm{y}^{-1}$ in restored forest, much higher than our $3.9 \mathrm{Mg} \mathrm{ha}^{-1} \mathrm{y}^{-1}$ estimate. Whilst AGB accumulation rates of over $12 \mathrm{Mg} \mathrm{ha}^{-1} \mathrm{y}^{-1}$ have been recorded in the tropics (e.g. Fehse et al., 2002; Hertel et al., 2009), these have generally be located in habitats different to that found in Kibale. For example Fehse et al. (2002) estimated AGB accumulation of $14.2 \mathrm{Mg} \mathrm{ha}^{-1} \mathrm{y}^{-1}$ during the first 8 years following logging, however, this was in high altitude $(>3000 \mathrm{~m})$ forest in
Ecuador. The high AGB accumulation rate estimated by Preece et al. could be a result of AGB accumulation being averaged across three different planting types, which included eucalyptus plantations, mixed timber plantations, and diverse 'ecological' plantations. The inclusion of fast growing eucalyptus plantations may have resulted in a higher accumulation rate that is not representative of biomass accumulation in ecological restoration projects if measured alone.

A recent pair of studies (Martin et al., 2013; Poorter et al., 2016) predicted the time it would take for the AGB of abandoned agricultural land to reach that seen in old-growth. In a meta-analysis of 74 studies Martin et al. (2013), found that tropical secondary forest, with no management interventions, reached old-growth forest AGB in an average of 80 years. Meanwhile, in an analysis of 45 neotropical sites, Poorter et al. (2016) predicted it would take 66 years for abandoned agricultural land to attain 90\% of oldgrowth forest AGB. In both cases this is shorter than the further 96 years predicted in this study for restoration forest to reach old-growth forest AGB. There are a number of possible explanations for this difference. Firstly, the majority of studies used by Martin et al. (2013) and all of the site in Poorter et al. (2016) were from Latin America and therefore may have different climatic conditions to Kibale. Secondly, in Martin et al. their definition of secondary forest was 'previously forested land undergoing secondary succession following total or near total removal of trees'. Therefore, some areas may have started with higher initial AGB than the low $5 \mathrm{Mg} \mathrm{ha}^{-1}$ at Kibale. Thirdly, Poorter et al. excluded sites that were experiencing arrested succession, as was the case in Kibale, and state that this could lead to slight overestimation of recovery rates. Finally, the AGB of old-growth forest may be lower than the $415 \mathrm{Mg} \mathrm{ha}^{-1}$ seen in Kibale, as AGB is lower over large areas of Latin America compared to Africa, meaning oldgrowth levels are attained more quickly (c.f. Amazon and Africa AGB, Baker et al., 2004; Lewis et al., 2013).

In the 18 years since planting, the 1305 ha in the Phase one planting area (where all restoration plots are located) have sequestered an estimated $24,920 \mathrm{Mg}$ of carbon (lower and upper confidence interval $=20,198-29,643 \mathrm{Mg}$ of carbon. Carbon $=47.1 \%$ $( \pm 0.4)$ of AGB, Thomas and Martin, 2012). In subsequent planting phases an additional 1936 ha have been planted (3241 ha planted in total to date). Using the accumulation rates calculated in this study an estimated $47,770 \mathrm{Mg}$ of Carbon has been sequestered by the UWA-FACE project by 2013. If the entire 10,000 ha project area were planted and fully restored to reach old-growth forest levels of aboveground carbon storage, the UWA-FACE project area would sequester $\sim 2 \mathrm{Tg}$ carbon (range $1.5-2.5 \mathrm{TgC}$, 1 Teragram $=10^{12}=1$ million $\mathrm{Mg}$ ). Indeed, $2 \mathrm{Tg} \mathrm{C}$ is a minimum estimate as it excludes belowground and necromass carbon pools. In oldgrowth forest carbon storage in belowground and necromass pools are $\sim 25 \%$ and $\sim 13 \%$ of aboveground carbon, respectively (Deans et al., 1996; Lewis et al., 2009; Phillips et al., 2008), which would contribute an additional $\sim 0.8 \mathrm{Tg} \mathrm{C}$. This is a first-order estimate, as aboveground to belowground and necromass ratios may differ with forest age and structure. Preece et al. (2015) found an aboveground to belowground ratio of $24 \%$ in young ecological restoration forest, planted on abandoned pasture, suggesting that this is a reasonable estimate for belowground carbon stocks in the UWA-FACE project. Over the whole project there is a very large potential store of carbon showing the benefits of active forest restoration in an area of degraded forest affected by arrested succession.

All project activities, which include: preparation of land for planting $\left(\sim 10\right.$ person days ha $\left.{ }^{-1}\right)$; planting seedlings $(\sim 7$ person days ha $\left.{ }^{-1}\right)$; management of grasses surrounding planted seedlings ( $\sim 3$ person days ha ${ }^{-1}$ ); and maintenance of firebreaks cost $\sim \$ 1200$ per ha over 5 years (UWA-FACE, 2011). If all 10,000 ha of the project area were fully restored the full project costs would 
be $\$ 12$ million. Assuming that the entire project area were accumulating carbon at a rate of $1.85 \mathrm{Mg} \mathrm{ha}^{-1} \mathrm{y}^{-1}$ (i.e. $3.9 \mathrm{Mg} \mathrm{ha}^{-1} \mathrm{y}^{-1}$ of dry biomass with a carbon content of $47.1 \%$ or $18,500 \mathrm{Mg} \mathrm{y}^{-1}$ across the whole project area), for the project to break-even within 20 years, carbon would need to be priced at $\$ 32$ per tonne (i.e. $\$ 12$ million $/ 20$ years $=\$ 600,000$ per year to sequester $18,500 \mathrm{MgC}^{-1}=\$ 32$ per tonne). Including belowground carbon and longer projects, of course, both lower carbon prices. This shows that allocating a relatively high carbon prices are necessary if funding for restoration projects such as this is to become readily available.

\subsection{Effects of active restoration on biodiversity}

These study results also suggest that forest restoration is beneficial for plant biodiversity, with both trees $\geqslant 10 \mathrm{~cm}$ DBH and seedlings $<2 \mathrm{~m}$ increasing in species richness and evenness since planting (Table 4). However, biodiversity of trees and seedlings is still significantly lower than old-growth forest (Table 4). Furthermore, restoration and old-growth plot had markedly difference species composition (Fig. 4). These results support the hypothesis that forest restoration will improve biodiversity, but species composition will take longer to reach old-growth forest levels than AGB, as early successional pioneers tree species, which make up the majority of planted stems are relatively rarely found in oldgrowth forest. Species composition will become more similar to that of old-growth forest only after the planted pioneer species are superseded, which usually takes a few decades - the average lifespan of many pioneer species (Rees et al., 2001). This is in accordance with a meta-analysis by Martin et al. (2013) who found that in secondary forest, AGB recovery was more rapid than biodiversity recovery. They estimated that tree diversity would reach oldgrowth forest levels within 100 years, 20 years longer than for ABG to reach old-growth forest levels. They suggested this was a result of the sensitivity of old-growth forest specialists to human disturbance, coupled with small ranges and populations of oldgrowth species. However, while forest restoration has often been suggested as an important possible approach to slowing biodiversity losses (Bekessy and Wintle, 2008), and changes in biodiversity have been well documented in natural regenerating forest (Barlow et al., 2007; Martin et al., 2013), to our knowledge ours if the first study into the effect of active restoration on plant biodiversity. Our study highlights the co-benefits that forest restoration may secure for plant biodiversity and carbon sequestration.

\subsection{Necessity of active restoration}

Without restoration activities it is likely that natural regeneration in Kibale would be extremely limited. This is evident in grassland plots that were not protected from fire and remain dominated by the grass $P$. purpureum 22 years after farming was abandoned, where AGB is $5.1 \mathrm{Mg} \mathrm{ha}^{-1}$. These grassland areas have undergone a burning regime since abandonment in 1992, similar to that which replanted areas experienced prior to the building of firebreaks and planting. The occasional trees present in grassland were generally fire resistant species, such as Erythrina abyssinica, Combretum molle, and Acacia spp.

Besides managing fire, the planting of seedlings is important for the restoration of heavily degraded land, as after 18 years, almost $70 \%$ of AGB is stored in planted trees. Furthermore, planted stems have a much higher $A G B$ accumulation rate than non-planted stems, at $3.1 \mathrm{Mg} \mathrm{ha}^{-1} \mathrm{y}^{-1}$ verses $0.7 \mathrm{Mg} \mathrm{ha}^{-1} \mathrm{y}^{-1}$ (Table 1 ). It is likely that this higher rate of accumulation results from planted stems being given a competitive advantage over non-planted stems due to the regular removal of surrounding grasses early in the restoration process. This assumption is supported by the growth seen in naturally regenerating seedlings that underwent the same management (cutting of grasses) as planted seedlings. These included S. ellipticum, which were not planted, but treated in the same way, when they occurred at planting points, which by 2013 was the third most common tree in the planted stands. This suggests that the tending of seedlings, notably reducing competition with grasses, is an important management intervention. Of course, adopting tending of naturally regenerating seedlings as a management technique is dependent on the abundance of naturally regenerating seedlings in grassland areas, which in this study was only $\sim 30$ individuals per ha. Cost may become important, as planting in lines to a standard plan gives easier management and possible economies of scale. However, our findings suggest that management to assist the competitive release of naturally regenerating seedlings deserves further study.

Although it is clear that restoration in this heavily degraded region is essential for recovery of AGB and biodiversity, it is unclear whether the combination of fire protection and replanting is necessary for successful restoration or whether fire protection alone would be a suitable restoration technique. A study by Omeja et al. (2011b) estimated AGB in a 0.5 ha grassland plot that was protected from fire for 32 years, also located within Kibale. They found that after 32 years of natural regeneration, AGB of stems $\geqslant 10 \mathrm{~cm} \mathrm{DBH}$ was $29.9 \mathrm{Mg} \mathrm{ha}^{-1}$, accumulating at a rate of $0.9 \mathrm{Mg} \mathrm{ha} \mathrm{M}^{-1} \mathrm{y}^{-1}$. They also observed species richness, of trees $\geqslant 10 \mathrm{~cm} \mathrm{DBH}$, of 24 species per 0.5 ha plot. This result suggests that natural regeneration of $A G B$ and biodiversity is possible if areas are just protected from fire. However, AGB accumulation in this fireonly protected area is slower than measured in the UWA-FACE project, with an AGB of $40.6 \mathrm{Mg} \mathrm{ha}^{-1}$ after 18 years. If AGB were to continue accumulating at the estimated rate of $3.9 \mathrm{Mg} \mathrm{ha}^{-1} \mathrm{y}^{-1}$, after 32 years the AGB in restoration forest could potentially reach 95.2 $\mathrm{Mg} \mathrm{ha}^{-1}$, more than triple that seen in areas just protected from fire. While Omeja et al. (2011b) only studied a single 0.5 ha fire protected plot, it suggests that the combination of fire protection, planting, and the regular removal of nearby competitors of these seedlings, accelerate carbon sequestration and biodiversity increases compared to fire protection alone.

\subsection{Problems with active restoration}

After 18 years, only 15 of the 39 species that were originally planted were observed in the 50 sample plots. B. micrantha and $W$. ugandensis, were the dominant species in 2013, but made up $<5 \%$ of originally planted stems. Both are pioneer species rarely seen in old-growth forest (Katende et al., 1995; UWA-FACE, 2011). Conversely, $M$. platycalyx, $U$. congensis, $P$. africana, and $M$. bagshawei each constituted $>10 \%$ of originally planted stems (Table 3), but were rarely encountered in 2013, making up between $0.4 \%$ and $3 \%$ of planted stems (Table 3 ). The low encounter rate of commonly planted species demonstrates the importance of selecting species with high seedling survival. Pilot studies to evaluate which survival will be extremely useful in improving future restoration, as noted previously in the literature (e.g. Breugel et al. (2011) in a Brazilian context).

The UWA-FACE project adopted a more-or-less trial and error approach. Early planting regimes were monitored to improve the next round of species selection and planting. In the Phase 1 planting area, where this study was carried out, 39 different species were planted, reduced to 22 in Phase 2 and 3 (1997-2002), 16 in Phase 4 and 5 (2003-2006), and 10 species in Phase 6 (2007 onwards). These 10 species with low mortality and high growth rates are; B. micrantha (Euphorbiaceae), Cordia africana (Boraginaceae), Cordia mellenii (Boraginaceae), Croton macrostarchys (Euphorbiaceae), Croton megalcarpus (Euphorbiaceae), Ficus natalensis (Moraceae), M. bagshawei, P. africana, Spathodea campanulata 
(Bigogiaceae) and W. ugandensis (Canellaceae) (UWA-FACE, 2011). This has led to some Phase 2 and 3 areas resembling the 18 year old restoration forest in Phase 1 after only 11-16 years (lead author, personal observation).

Possibly the biggest ecological problem that could influence the continuation of the forest restoration, is the invasion of the dense shrub L. camara, which is the most common shrub in plots in both 2005 and 2013. Native to South America, L. camara is planted in nearby villages as an ornamental shrub. It is an extremely fast growing shrub that forms dense thickets, shading out the forest floor and inhibiting the regeneration of seedlings (Zalucki et al., 2007). Across most of its invasive range the spread of $L$. camara is not considered to be under sufficient control (Zalucki et al., 2007). Management of $L$. camara may be required in the future, which may include; slashing of plants at base, burning, uprooting, chemical control with herbicides and biological control using natural predators (Love et al., 2009).

\section{Conclusion}

This study adds to the very limited active forest restoration literature. Just three studies were found that monitored restored forest over 18 years, as has been done in this study. However, these used forest chronosequences, thus no previous studies measure changes in AGB, over a long time period, using repeat censuses of permanent sample plots, as this study does, the most reliable sampling method.

It is clear that protection from fire, planting seedlings, and grass cutting, is a successful restoration method, leading to the recovery of above ground biomass, forest structure and biodiversity. Indeed, active restoration of this site is essential for the recovery of this highly degraded area as $\sim 70 \%$ of AGB is stored in planted stems after 18 years. However, restoration is a slow process with $\sim 100$ years required for restoration forest to reach old-growth forest levels of AGB. For species composition, the delay is likely to be much longer. Therefore, the continued protection of this area is essential if restoration forest is to reach old-growth forest levels of biodiversity and carbon storage.

The continued monitoring of permanent sample plots into the future is needed to understand the long-term dynamics of recovery in restoration forest. The large increase in AGB accumulation from $0.95 \mathrm{Mg} \mathrm{ha}^{-1} \mathrm{y}^{-1}$ between 0 and 10 years to $3.9 \mathrm{Mg} \mathrm{ha}^{-1} \mathrm{y}^{-1}$ between 10 and 18 years demonstrates that short-term studies are not accurate in determining long-term trends in restoration forest. The sizeable carbon sequestration benefits possible, $\sim 2 \operatorname{Tg} C$ if all 10,000 ha were restored and attained old-growth AGB level, from this project supports the idea of ecologically friendly tropical forest restoration under schemes such as REDD+, whilst also offering the co-benefit of biodiversity conservation.

\section{Acknowledgements}

This research was supported by the Natural Environment Research Council, under a NERC CASE (collaborative award in science and engineering) studentship. We would like to thank CASE partners Permian Global for financial support, in particular Henrrieta Boyd. S.L.L. was supported by a Leverhulme Prize award. Additionally, funding was provided by Canada Research Chairs Program, Wildlife Conservation Society, Natural Science and Engineering Research Council of Canada, National Geographic, and Fonds Québécois de la Recherche sur la Nature et les Technologies. We also thank the Ugandan Wildlife Authority, FACE the future foundation and the Uganda National Council for Science and Technology for allowing us to conduct this research. Thanks to Makerere University Biological Field Station for providing logistical support.
Finally we thank the field assistants King Solomon, Polycarp Miuesigwa and Sunday John who helped with data collection and species identification.

\section{Appendix A. Supplementary material}

Supplementary data associated with this article can be found, in the online version, at http://dx.doi.org/10.1016/j.foreco.2016.04. 025 .

\section{References}

Baker, T.R., Phillips, O.L., Malhi, Y., et al., 2004. Increasing biomass in Amazonian forest plots. Philos. Trans. R. Soc. Lond. Ser. B - Biol. Sci. 359, 353-365.

Baranga, J., 1991. Kibale Forest Game Corridor: Man or Wildlife? Surrey Beatty \& Sons, Australia.

Barlow, J., Gardner, T.A., Araujo, I.S., et al., 2007. Quantifying the biodiversity value of tropical primary, secondary, and plantation forests. Proc. Natl. Acad. Sci. USA 104, 18555-18560.

Bekessy, S.A., Wintle, B.A., 2008. Using carbon investment to grow the biodiversity bank. Conserv. Biol. 22, 510-513.

Breugel, M.V., Hall, J.S., Craven, D.J., et al., 2011. Early growth and survival of 49 tropical tree species across sites differing in soil fertility and rainfall in Panama. For. Ecol. Manage. 261, 1580-1589.

Catterall, C.P., Freeman, A.N., Kanowski, J., Freebody, K., 2012. Can active restoration of tropical rainforest rescue biodiversity? A case with bird community indicators. Biol. Conserv. 146, 53-61.

Chapman, C.A., Lambert, J.E., 2000. Habitat alteration and the conservation of African primates: case study of Kibale National Park, Uganda. Am. J. Primatol. 50, 169-185.

Chave, J., Muller-Landau, H.C., Baker, T.R., Easdale, T.A., Ter Steege, H., Webb, C.O., 2006. Regional and phylogenetic variation of wood density across 2456 neotropical tree species. Ecol. Appl. 16, 2356-2367.

Chave, J., Réjou-Méchain, M., Búrquez, A., et al., 2014. Improved allometric models to estimate the aboveground biomass of tropical trees. Global Change Biol. 20, 3177-3190.

Chazdon, R.L., Brancalion, P.H.S., Laestadius, L., et al., 2016. When is a forest a forest? Forest concepts and definitions in the era of forest and landscape restoration. Ambio, 1-13.

Cochrane, M.A., 2003. Fire science for rainforests. Nature 421, 913-919.

Cubiña, A., Aide, T.M., 2001. The effect of distance from forest edge on seed rain and soil seed bank in a tropical pasture. Biotropica 33, 260-267.

Deans, J.D., Moran, J., Grace, J., 1996. Biomass relationships for tree species in regenerating semi-deciduous tropical moist forest in Cameroon. For. Ecol. Manage. 88, 215-225.

Dupuy, J.M., Chazdon, R.L., 1998. Long-term effects of forest regrowth and selective logging on the seed bank of tropical forests in NE Costa Rica. Biotropica 30, 223 237.

Fehse, J., Hofstede, R., Aguirre, N., Paladines, C., Kooijman, A., Sevink, J., 2002. High altitude tropical secondary forests: a competitive carbon sink? For. Ecol. Manage. 163, 9-25.

Finegan, B., 1996. Pattern and process in neotropical secondary rain forests: the first 100 years of succession. Trends Ecol. Evol. 11, 119-124.

Hertel, D., Moser, G., Culmsee, H., Erasmi, S., Horna, V., Schuldt, B., Leuschner, C. 2009. Below- and above-ground biomass and net primary production in a paleotropical natural forest (Sulawesi, Indonesia) as compared to neotropical forests. For. Ecol. Manage. 258, 1904-1912.

Hill, M.O., 1973. Diversity and evenness: a unifying notation and its consequences. Ecology 54, 427-432.

Holl, K.D., 1999. Factors limiting tropical rain forest regeneration in abandoned pasture: seed rain, seed germination, microclimate, and soil. Biotropica 31, 229-242.

Kanowski, J., Catterall, C., Wardell-Johnson, G., Proctor, H., Reis, T., 2003. Development of forest structure on cleared rainforest land in eastern Australia under different styles of reforestation. For. Ecol. Manage. 183, 265280.

Katende, A.B., Birnie, A., Tengnas, B., 1995. Useful trees and shrubs for Uganda. Identification, propagation and management for agricultural and pastoral communities. Regional Soil Conservation Unit, Nairobi, 9966, 22.

Kohyama, T., 1986. Tree size structure of stands and each species in primary warmtemperate rain forests of southern Japan. The Botanical Magazine $=$ Shokubutsu-gaku-zasshi 99, 267-279.

Lamb, D., Erskine, P., Parrotta, J., 2005. Restoration of degraded tropical forest landscapes. Science 310, 1628-1632.

Lawes, M., Chapman, C., 2006. Does the herb Acanthus pubescens and/or elephants suppress tree regeneration in disturbed Afrotropical forest? For. Ecol. Manage. $221,278-284$.

Leblanc, S.G., Chen, J.M., Fernandes, R., Deering, D.W., Conley, A., 2005. Methodology comparison for canopy structure parameters extraction from digital hemispherical photography in boreal forests. Agric. For. Meteorol. 129, $187-$ 207. 
Lepš, J.Š., Šmilauer, Petr, 2003. Multivariate Analysis of Ecological Data Using CANOCO. Cambridge University Press, New York.

Lewis, S.L., Lopez-Gonzalez, G., Sonke, B., et al., 2009. Increasing carbon storage in intact African tropical forests. Nature 457, 1003-1006.

Lewis, S.L., Sonké, B., Sunderland, T., et al., 2013. Above-ground biomass and structure of 260 African tropical forests. Philos. Trans. R. Soc. B: Biol. Sci. 368.

Lichstein, J.W., Wirth, C., Horn, H.S., Pacala, S.W., 2009. Biomass chronosequences of United States forests: implications for carbon storage and forest management. In: Old-Growth Forests. Springer, pp. 301-341.

Love, A., Babu, S., Babu, C.R., 2009. Management of Lantana, an invasive alien weed, in forest ecosystems of India. Curr. Sci. 97, 1421-1429.

Martin, P.A., Newton, A.C., Bullock, J.M., 2013. Carbon pools recover more quickly than plant biodiversity in tropical secondary forests. Proc. R. Soc. B - Biol. Sci. 280.

Oksanen, J., Blanchet, F.G., Kindt, R., Legendre, P., Minchin, P.R., O'Hara, R.B. Simpson, G.L., Solymos, P., Henry, M., Stevens, H, Wagner, H., 2013. Vegan: Community Ecology Package. <http://CRAN.R-project.org/package=vegan>.

Omeja, P., Chapman, C., Obua, J., Lwanga, J., Jacob, A.L., Wanyama, F., Mugenyi, R., 2011a. Intensive tree planting facilitates tropical forest biodiversity and biomass accumulation in Kibale National Park, Uganda. For. Ecol. Manage. 261, 703-709.

Omeja, P., Lwanga, J., Obua, J., Chapman, C., 2011b. Fire control as a simple means of promoting tropical forest restoration. Trop. Conserv. Sci. 4, 287-299.

Osmaston, H.A., 1959. Forestry Working Plan for the Kibale and Itwara Forests. Uganda Forest Department, Entebbe, Uganda.

Pan, Y., Birdsey, R.A., Fang, J., et al., 2011. A large and persistent carbon sink in the world's forests. Science 333, 988-993.

Parrotta, J.A., Knowles, O.H., 1999. Restoration of tropical moist forests on BauxiteMined lands in the Brazilian Amazon. Restor. Ecol. 7, 103-116.

Paul, J.R., Randle, A.M., Chapman, C.A., Chapman, L.J., 2004. Arrested succession in logging gaps: is tree seedling growth and survival limiting? Afr. J. Ecol. 42, 245 251.

Paul, K.I., Roxburgh, S.H., England, J.R., et al., 2015. Improved models for estimating temporal changes in carbon sequestration in above-ground biomass of mixedspecies environmental plantings. For. Ecol. Manage. 338, 208-218.

Philipson, C.D., Dent, D.H., O'brien, M.J., et al., 2014. A trait-based trade-off between growth and mortality: evidence from 15 tropical tree species using size-specific relative growth rates. Ecol. Evol. 4, 3675-3688.

Phillips, O., Baker, T., Feldpausch, T., Brienen, R., 2009. RAINFOR Field Manual for Plot Establishment and Remeasurement. <http://www.rainfor.org/ en/manuals>.
Phillips, O.L., Lewis, S.L., Baker, T.R., Chao, K.J., Higuchi, N., 2008. The changing Amazon forest. Philos. Trans. R. Soc. B - Biol. Sci. 363, 1819-1827.

Poorter, L., Bongers, F., Aide, T.M., et al., 2016. Biomass resilience of Neotropical secondary forests. Nature 530, 211-214.

Preece, N.D., Crowley, G.M., Lawes, M.J., Van Oosterzee, P., 2012. Comparing aboveground biomass among forest types in the Wet Tropics: small stems and plantation types matter in carbon accounting. For. Ecol. Manage. 264, 228-237.

Preece, N.D., Lawes, M.J., Rossman, A.K., Curran, T.J., Van Oosterzee, P., 2015 Modelling the growth of young rainforest trees for biomass estimates and carbon sequestration accounting. For. Ecol. Manage. 351, 57-66.

R Core Team, 2013. R: A Language and Environment for Statistical Computing. R Foundation for Statistical Computing, Vienna, Austria, <http://www.R-project. org/>.

Rees, M., Condit, R., Crawley, M., Pacala, S., Tilman, D., 2001. Long-term studies of vegetation dynamics. Science 293, 650-655.

Sheil, D., May, R.M., 1996. Mortality and recruitment rate evaluations in heterogeneous tropical forests. J. Ecol. 84, 91-100.

Struhsaker, T.T., 1997. Ecology of an African Rainforest: Logging in Kibale and the Conflict between Conservation and Exploitation. University Press of Florida, Gainsville, Florida.

Talbot, J., Lewis, S.L., Lopez-Gonzalez, G., et al., 2014. Methods to estimate aboveground wood productivity from long-term forest inventory plots. For. Ecol. Manage. 320, 30-38.

Thomas, S.C., Martin, A.R., 2012. Carbon content of tree tissues: a synthesis. Forests $3,332-352$.

Uwa-Face, 2007. Natural high forest rehabilitation project on degraded land of Kibale National Park. In: Verified Carbon Standard Project Description Template.

Uwa-Face, 2011. UWA-FACE the Future Annual Plan of Operation. Uganda Wildlife Authority, Fort Portal, Uganda.

Van Orsdol, K.G., 1986. Agricultural encroachment in Uganda's Kibale Forest. Oryx 20, 115-117.

Whitmore, T.C., 1998. An Introduction to Tropical Rain Forests. Oxford University Press, Oxford.

Zalucki, M., Day, M., Playford, J., 2007. Will biological control of Lantana camara ever succeed? Patterns, processes \& prospects. Biol. Control 42, 251-261.

Zanne, A.E., Lopez-Gonzalez, G., Coomes, D.A., Ilic, J., Jansen, S., Lewis, S.L., Miller, R. B., Swenson, N.G., Wiemann, M.C., Chave, J., 2009. Global Wood Density Database, Dryad. <http://hdl.handle.net/10255/dryad.235>. 